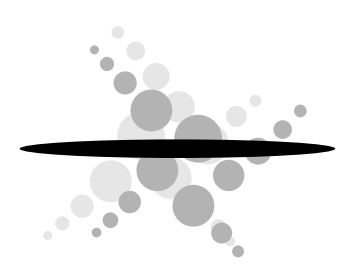

\title{
結晶構造解析によるイエロープロテインの 光反応モデルと炎の問題点
}

奈良先端科学技術大学院大学物質創成科学研究科 清水伸隆, 今元 泰, 片岡幹雄

\begin{abstract}
The reaction mechanism of photoactive yellow protein (PYP) has been proposed based on the high-resolution $\mathrm{x}$-ray crystal structure models of the photocycle intermediates. After the analysis, infrared and UV/Visible spectroscopic studies have been carried out on the intermediates in wild-type and mutated PYP. However, the data from the spectroscopic studies are not consistent with the proposed structural models and the reaction mechanism. Here, we describe the conflicts between the crystallographic and spectroscopic studies and discuss the reaction mechanism of $\mathrm{PYP}$ in solution.
\end{abstract}

X-ray crystallography / spectroscopy / photocycle / protein structure / photoreceptor

\section{1.はじめに}

生体内情報は, 受容体タンパク質をはじめとするさま ざまな生体分子が相互作用することによって伝達され る. したがって, 情報伝達のメカニズムを理解するため には, 個々の分子が, どのようにして情報伝達の ON/OFFを切り替えているのかを解明しなければなら ない.たとえば, 受容体タンパク質の場合, ターゲット分 子と相互作用できない刺激前と, 相互作用か河能にな つた刺激後のグローバルな構造変化を明らかにしなけ ればならない

さまざまな受容体タンパク質のなかでも, 最も広く研 究されているのは光受容タンパク質であろう. 光受容 タンパク質は, 光刺激で反応をトリガーできるため, 反 応の開始か容易で実験上便利である. また, 光受容タン パク質は可視光吸収のために補欠分子である発色団を もっている. 光吸収に伴う発色団の構造変化は, タンパ ク質部分との相互作用を変化させるため, 吸収スペク トルか変化する. したがって, 受容体タンパク質の構造 变化を, 可視分光という比較的簡単な手法によって追 跡することができる. 以上のような利点から, 外部刺激 にともなう受容体タンパク質の高次構造変化や反応メ カニズムの解析のためには, 光受容タンパク質は最も 好適な研究対象である. 特に, 本稿で取り上げる pho- toactive yellow protein (PYP) は, 比較的低分子量の水 溶性タンパク質であることから結晶化が容易である. このため結晶構造解析を行うことによって, 高次構造 に基づいた研究が展開できると期待され, 実際产のよ うに研究は進んできた. しかし, PYPの研究は, 本来な らば構造を解く上で傍証となるべき赤外・紫外/可視 などの分光学的なデータの蓄積を待たずに結晶構造解 析が先行した特異な例である. 弚のため, 後から分光学 的データが得られるようになると, 反応中間体の結晶 構造モデルにさまざまな問題点があることが明らかに なってきた.ここではPYPのこれまでの内外の結晶学 的・分光学的研究を総括し, 現在の問題点を検証して みたい。

\section{PYPについて}

PYPは, 紅色光合成細菌Ectothiorhodospira halophila の産生する水溶性の光受容タンパク質で, 菌体の負の 走光性のための光受容体である ${ }^{1)}$. アミノ酸残基は 125 個あり, 光れらは6 本鎖の逆平行 $\beta$ シート, 発色団結合 ループ, $3 つ$ のへリックスにより構成される中核部と,

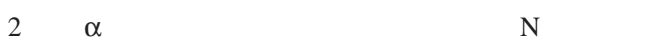
で構成される $\alpha / \beta$ 構造に折りたたまれる (図 1). 発色 団は69番目のシステインにチオエステル結合した4-ヒ ドロキシケイ皮酸 ( $p$-クマル酸) である (図2). 発色

The Progress and Problem of X-ray Crystallography of Photocycle Intermediate of Photoactive

\section{Yellow Protein}

Nobutaka SHIMIZU, Yasushi IMAMOTO and Mikio KATAOKA

Graduate School of Materials Science, Nara Institute of Science and Technology 

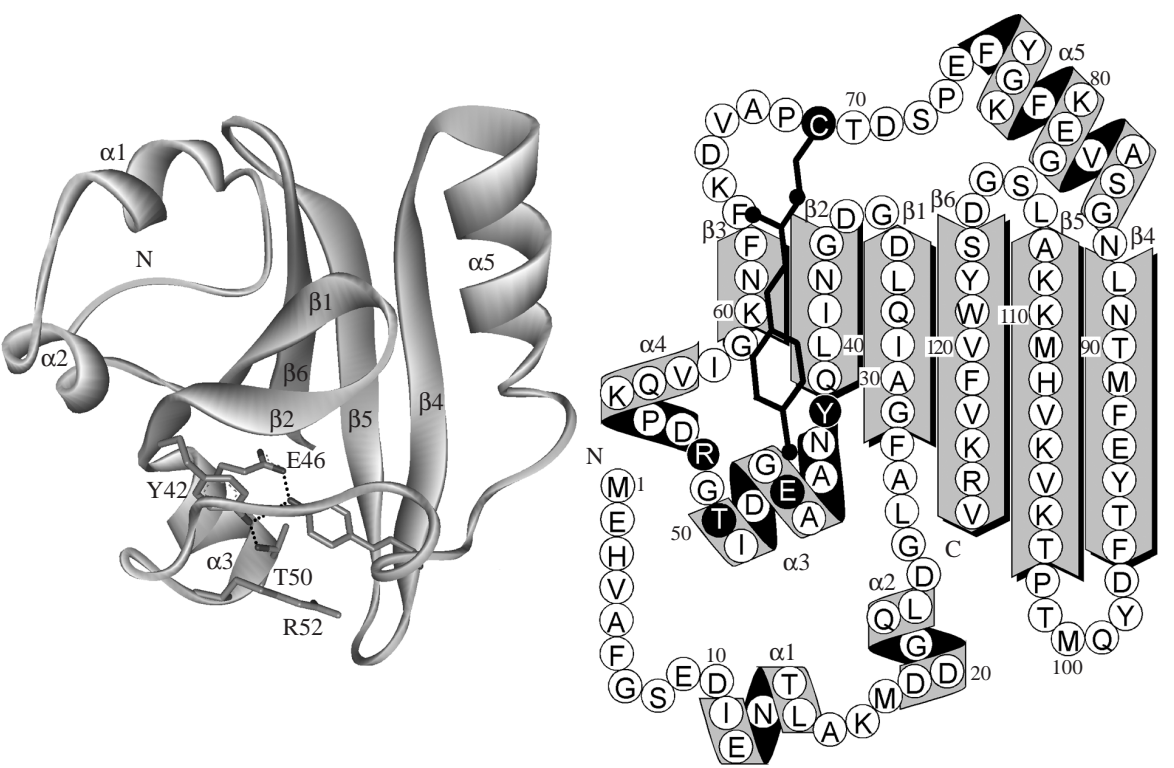

図1 PYPの立体構造のリボン図 (左) と模式図 (右)

PYP は 6 本鎖 $\beta$ シートと 5 つの $\alpha$ ヘックスからなる $\alpha / \beta$ タンパク質である. 左図に示した発色団の近傍のアミノ酸 $(\mathrm{Y} 42, \mathrm{E} 46$, T50, R52, C69) を, 右図では白抜きで示した.

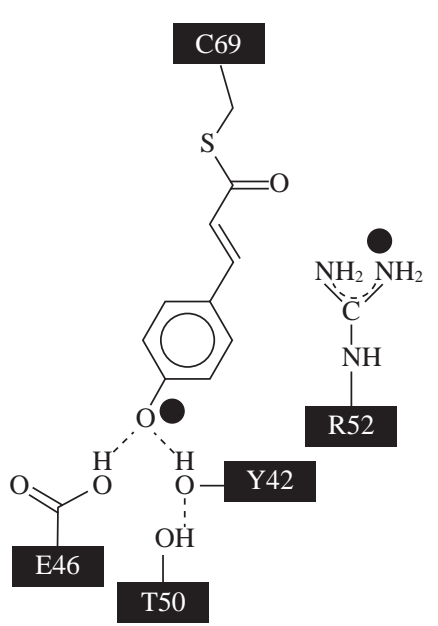

図2 暗状態PYPの発色団

発色団である4-ヒドロキシケイ皮酸は, C69 とチオエステ ル結合している. 発色団のフェノール酸素はY $42, \mathrm{E} 46$ と

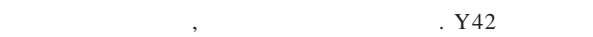
$\mathrm{T} 50$ とも相互作用している. 発色団の近傍にはR52があり, 発色団の負電荷を安定化していると考えられている.

団のフェノール酸素は, Y42, E46 と水素結合して脱プ ロトン化しているので, 負の電荷をもっている. 可視部 の吸収極大波長が446 nmにあるため, PYPは光の名の とおり明るい黄色を呈している. PYPが光を吸収する と, 発色団はトランス型からシス型へ異性化し, $\mathrm{PYP}_{\mathrm{B}}$, $\mathrm{PYP}_{\mathrm{H}}$ という2つの産物か甡成する (図3). 兴の後, 光れ

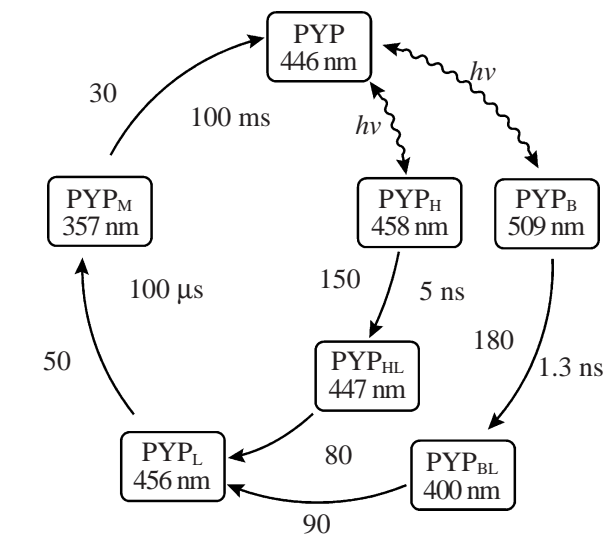

図3 PYPの光反応スキーム

室温での時定数と低温での安定温度を図に示した. 中間体 のよび方はまだ統一されていないので, 筆者らのものに従 つた. $\mathrm{PYP}_{\mathrm{B}}$ は $\mathrm{I} 0, \mathrm{PYP}_{\mathrm{L}}$ はI1 あるいは $\mathrm{pR}, \mathrm{PYP}_{\mathrm{M}}$ はI $\mathrm{I}$ ある いはpBともよばれる.

ぞれがPYP $\mathrm{P}_{\mathrm{L}}$ 変化し, $\mathrm{PYP}_{\mathrm{M}}$ を経て, もとのPYPに戻 る.これらの中間体は光れ光れ固有の吸収スペクトル をもっているので, 可視分光で区別することができる. 光反応サイクルに要する時間は, 条件によって大きく 異なるが,生理的条件では数100ミリ秒である.

PYPは分子量 14000 の水溶性タンパク質であること から, 発見後すぐに結晶化が行われた. 発見の翌年の 1986年には結晶のX線回折パターンが発表され, 1989 
年には一応構造が解かれたのであるが, 兴の構造モデ ルは $2 つ の 5$ 本鎖 $\beta$ シートをもつた $\beta$ クラ構造で, 126 個のアミノ酸残基と, 発色団として全トランス型レチ ナールを含むものであった. この構造は $2.4 \AA$ 分解能で の解析結果であつたが, まったくの誤りであつた. 現在 広く認められている1.4 A分解能て解かれた構造は, 同 じグループにより, 1995 年に訂正されたものである21 (PDB ID：2PHY). 光の後, 結晶構造解析の対象は光反 応中間体へと移っていき, 光励起前後の差フーリエマ ップから,さまざまな中間体の構造モデルが提唱され ることとなる

\section{PYP の光反応中間体の構造}

まず,結晶構造解析によって提唱された中間体の発色 団まわりの構造を見てみたい (図4上).これまでの報 告はいずれも, 中間体自体を結晶化したものではなく， 作成した暗状態のPYPの結晶に光を照射して光反応さ せることにより,結晶中で中間体を生成させて解析を 行ったものである.いくら強い光を照射しても光定常 状態力゙生成するため, 結晶中のすべてのPYPを中間体 に変換させることはできない, 弚のため, 光照射下の電 子密度から暗状態の電子密度を引いた, $|\mathrm{F}|_{\mathrm{light}}-|\mathrm{F}|_{\mathrm{dark}}$ 差 フーリエマップに基づいて構造変化部位を同定し, 光
反応メカニズムの議論が行われている.

$3.1 \mathrm{PYP}_{\mathrm{M}}$ (PDB ID : 2PYP)

PYPの反応中間体で最初に構造力提唱されたのは, 光 励起後ミリ秒領域で生成し, 活性中間体であると考えら れている $\mathrm{PYP}_{\mathrm{M}}$ (原著ではI2)である3). PYPの単結晶 を- $12^{\circ} \mathrm{C} て ゙ 496.5 \mathrm{~nm}$ の定常光レーザーで励起し, ミリ秒 領域の時分割ラウエ法が行われた. 時分割ラウエ法の詳 細は省略するが, $1.9 \AA$ 分解能で得られた $|F|_{\text {photostationary }}$ $|F|_{\text {dark }}$ の差フーリエマップにより, 構造変化を解析して いる. この構造を暗状態のものと比較すると, 発色団の チオエステル結合部分は产のままで, フェノール部分 が大きく回転することでシス型に異性化している (図 4上). 推定された $\mathrm{PYP}_{\mathrm{M}}$ の構造モデルでは, 暗状態でみ られたフェノール酸素と E46, Y42 との水素結合ネット ワークは完全に壞れ, R52 と新たな水素結合を形成して いる. R52 は溶媒に露出し, タンパク質表面の電荷分布 は変化しているが, 弚れ以外のタンパク質の全体構造 の変化は観測されていない(後述).

$3.2 \mathrm{PYP}_{\mathrm{BL}}$ (PDB ID : 3PYP)

次に提唱されたのは, $-180 \sim-90^{\circ} \mathrm{C} の$ 温度領域で 安定な $\mathrm{PYP}_{\mathrm{BL}}$ である ${ }^{4)}$. PYPの結晶に, $-124^{\circ} \mathrm{C} て ゙ 460$ $\mathrm{nm}$ の光 (バンド幅 $20 \mathrm{~nm}$ ) を 1 時間照射して光反応させ ている. $\mathrm{PYP}_{\mathrm{M}}$ の構造モデルと同樣に, $|\mathrm{F}|_{\text {photostationary }}-|\mathrm{F}|_{\text {dark }}$
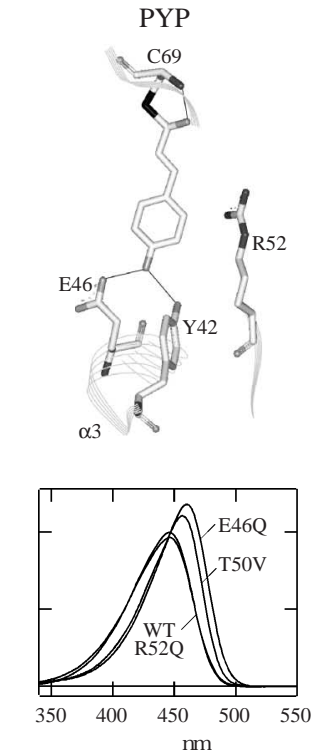
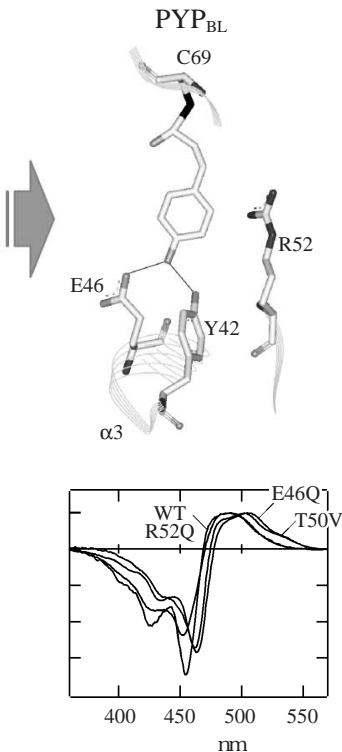

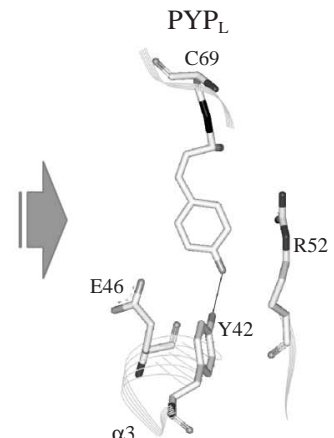

$\alpha 3$

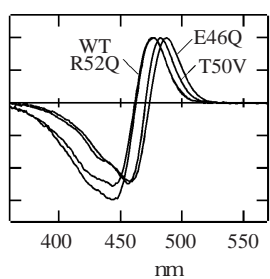

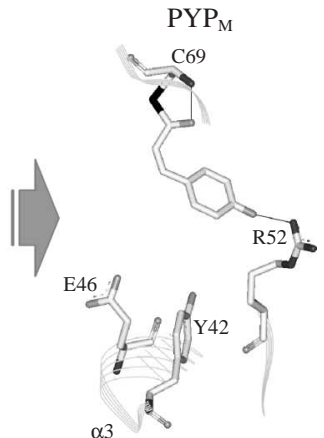

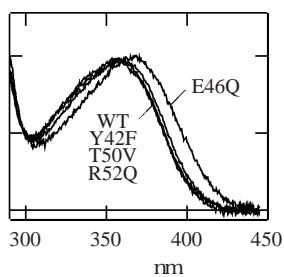

図4 上：X線結晶構造解析によって得られた $\mathrm{PYP}$ と光反応中間体, $\mathrm{PYP}_{\mathrm{BL}}, \mathrm{PYP}_{\mathrm{L}}, \mathrm{PY}_{\mathrm{M}}$ の発色団構造 図には示していないが, T50はY42を介して発色団と相互作用している (図2). 下 : Y42F, E46Q, T50V, R52Q変異体の吸収スペクトルと野生型 (WT) のものとの比較 $\mathrm{PYP}_{\mathrm{B}}$ と $\mathrm{PYP}_{\mathrm{L}}$ は暗状態との差スペクトル, 暗状態 $(\mathrm{PYP})$ と $\mathrm{PYP}_{\mathrm{M}}$ は吸収スペクトルの比較である. 発色団と水素結合している残基に变異を導入すると吸収スペクトルが変化し, 弚うでないものは変化しないはずだが.... 
の差フーリエマップ (分解能 $0.85 \AA$ ) より構造変化を 推定しているが, このモデルでは, チオエステルのC $=\mathrm{O}$ の回転により, 発色団は光異性化している (図4上). 光 のため, 暗状態で見られたチオエステルの酸素原子と C69の主鎖の窒素原子との水素結合は切断されている. 一方, 発色団の水素結合ネットワークをはじめとする 発色団結合ポケットにほとんど変化はなく, 発色団の フェノール酸素とY42, E46の位置関係は光のままであ る. また, タンパク質の構造も変化していない.この構造 から $\mathrm{PYP}_{\mathrm{M}}$ に変化するためには, 発色団はシス型のまま 全体がチオエステルの根元で半回転し, 芳香環部はR52 を向き, チオエステルの酸素原子とC69 の主鎖との水 素結合が復活するという, 大きな動きをしなければな らない. タンパク質内部という限られたスペースのな かで, このような大きな動きは難しいように思われる.

\section{3 $\mathrm{PYP}_{\mathrm{L}}$ (PDB ID : 2PYR)}

ナノ秒〜マイクロ秒で生成する $\mathrm{PYP}_{\mathrm{L}}$ (原著では $\mathrm{pR}$ ) の構造は, 時間分解能1ナノ秒での時分割ラウエ法によ り解析された ${ }^{5}$. 光反応のトリガーには $495 \mathrm{~nm}$ のパル

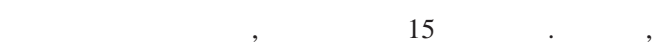
$1.9 \AA$ 分解能の $|\mathrm{F}|_{1 \mathrm{~ns}}-|\mathrm{F}|_{\mathrm{dark}}$ 差フーリエマップによる解 析を行っている. この解析によれば, 発色団のフェノー ル部分が, 弚の重心位置を変えないように面内で回転 してシス型に異性化している (図4上). 兴の結果, 水酸 基の方向のみか変わっており, $\mathrm{E} 46$ との水素結合は切断 されている. この構造は非常にねじれていて不安定な ため, $\mathrm{PYP}_{\mathrm{M}}$ への変化の過程で, 発色団はさらにR52 側 に傾き, 安定構造へと向かうと考えられている. $\mathrm{PYP}_{\mathrm{M}}$ の前駆体としてはこのモデルは妥当であるように思え るが, $\mathrm{PY}_{\mathrm{BL}}$ とは大きく違っており, $\mathrm{PY}_{\mathrm{BL}}$ からの産物 であるとは考えにくい

以上の $3 つ$ 結晶構造解析は, 差フーリエマップによ って座標が変化した原子を特定し, 光反応中間体の構 造を視覚的に表現したため, 非常に画期的であった. 実 際, PYPて研究するべきことはもはやなくなったと考 える研究者も多かったようである. しかし光の後, フー リエ変換赤外分光 (FT-IR) や変異体を用いた低温可 視分光など, いわば古典的な手法によるデータか蓄積 されてくると,多くの疑問が浮かび上がってきだ).

\section{4 . 赤外分光法·可視分光法による構造変化の解析}

最近, 低温FT-IR ${ }^{7)}$, あるいは溶液試料を用いた時間分 解FT-IR ${ }^{8)}$, 9) によるPYPの反応機構の詳しい解析が発 表された. まず, 発色団と水素結合しているE46のC $=\mathrm{O}$ 伸縮モードを $\mathrm{PYP}_{\mathrm{L}}$ で解析したところ, $\mathrm{PYP}_{\mathrm{L}}$ ではむし ろE46の水素結合は強くなっていた. 発色団のほかに
E46の水素結合パートナーは見当たらないため, $\mathrm{PYP}_{\mathrm{L}}$ でも発色団とE46 との水素結合は維持されており,切れ ることはないと考えられた. この結論は $\mathrm{PYP}_{\mathrm{L}}$ の構造解 析と矛盾している. また, タンパク質骨格の情報が得ら れるアミド I領域の変化から, 中心部の $\beta$ シート部分の 構造変化は, $\mathrm{PYP}_{\mathrm{L}}$ では生じていないが, $\mathrm{PYP}_{\mathrm{L}}$ から $\mathrm{PYP}_{\mathrm{M}}$ への変化過程で生じることが示唆された. このステッ プでE46から発色団ヘプロトンが移動する (発色団は プロトン化され, E46が脱プロトン化される)ので10), E46から発色団へのプロトン移動が原因となって, タン パク質全体におよぶような構造変化が生じると考えら れた.

一方, 低温FT-IR では, PYP, $\mathrm{PYP}_{\mathrm{B}}, \mathrm{PYP}_{\mathrm{H}}, \mathrm{PYP}_{\mathrm{L}}$ および

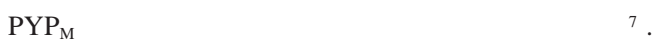
重水素ラベルした発色団をもつPYPを用いてこれらの バンドを同定したところ,いずれもビニル結合部分に 由来することが明らかとなったので, これらの構造の 違いは,ビニル結合部分にあると考えられた. 一方, E46 のC=O 伸縮モードの波数は, $\mathrm{PYP}_{\mathrm{B}}, \mathrm{PYP}_{\mathrm{H}}, \mathrm{PYP}_{\mathrm{L}}$ で同じ であることから, 水素結合強度が同じ, すなわち発色団 のフェノール部分の変化は小さいことがわかった.つ まり, PYPの光反応サイクルは, フェノール部分の向き が変化していくのではなく, エステル部分の回転によ りビニル結合部分のねじれが緩和していくことで進行 すると考えられた

発色団の構造情報を得るには, 吸収スペクトル測定が 最も直接的であり, 実際, 中間体の可視分光も行われて いる. PYPの発色団はY42, E46, T50 と水素結合ネット ワークを形成している(T50はY42を介して間接的に 発色団と相互作用している). これらの相互作用が, 発 色団の共役二重結合系に影響をおよぼすため, 上記の3 つの残基に部位特異的な変異を導入すると吸収スペク トルか変化する ${ }^{11)}$ (図4下). 一方で, R52 は発色団と水 素結合を形成しないので, これに変異を加えても吸収 スペクトルは変化しない. このように, 発色団周辺の水 素結合の状態を, 吸収スペクトルの変化で推測するこ とが可能である. 乥こで, 変異体を用いた吸収スペクト ル測定を中間体についても行い, 中間体でのタンパク 質/発色団相互作用を解析した ${ }^{12}$.

光照射によって $\mathrm{PYP}_{\mathrm{BL}}$ を単独で蓄積することは困難 なので, この実験では光の前駆体である $\mathrm{PYP}_{\mathrm{B}}$ のスペク トルを測定している. 野生型と変異体の $\mathrm{PY}_{\mathrm{B}}$ および $\mathrm{PYP}_{\mathrm{L}}$ のスペクトルを測定し, 野生型と比較したところ, E46Q, T50V, R52Q变異体での吸収極大の波長シフト の程度が, いずれも暗状態で観測されたものと同じで あった $(\mathrm{E} 46 \mathrm{Q}>\mathrm{T} 50 \mathrm{~V}>\mathrm{R} 52 \mathrm{Q}=$ 野生型 $)$. 谷のため, 
発色団のフェノール酸素の水素結合ネットワークは, $\mathrm{PYP}_{\mathrm{L}}$ までは保存されていると考えられた. この結果は, $\mathrm{PYP}_{\mathrm{BL}}$ の結晶構造モデルと矛盾しないが, フェノールの 向きが変わるとする $\mathrm{PY}_{\mathrm{L}}$ の結晶構造モデルとは相反 している. 一方, $\mathrm{PYP}_{\mathrm{M}}$ では, E46Qのみ長波長シフトし ていた $(\mathrm{E} 46 \mathrm{Q}>\mathrm{Y} 42 \mathrm{~F}=\mathrm{T} 50 \mathrm{~V}=\mathrm{R} 52 \mathrm{Q}=$ 野生型 $)$. 光 のため, $\mathrm{PYP}_{\mathrm{M}}$ の生成時には発色団と E46 との相互作用 は保たれるがY42 との相互作用か弱くなること, また, R52Qの効果がないことから, R52 との新たな水素結合 の形成もないと考えられた.この結果は, $\mathrm{PYP}_{\mathrm{M}}$ では発 色団の水素結合パートナーがE46から R52 に変化する という結晶構造モデルとは矛盾するものとなった.

以上, 分光学的データから PYPの光反応機構を推測 すると, 以下のようになる. まず, 暗状態の発色団は, 脱 プロトン化したトランス型であるが, 光吸収でチオエ ステルのC $=\mathrm{O}$ 部分が回転し, シス型に異性化する. この とき, フェノール周りの環境は変化せず, 水素結合ネッ トワークは保たれたままである. 产の後, ビニル結合の ねじれの緩和によって $\mathrm{PYP}_{\mathrm{L}}$ か甡成する. 汭て, E46か ら発色団にプロトンか移動すると, E46 と発色団の水素 結合は保たれたままY42 との水素結合が切れ, 大きな 構造変化が起こると考えられる. 結局, 結晶構造解析で 提唱された 3 つ構造のうち, $\mathrm{PY}_{\mathrm{BL}}$ の構造は分光学的 実験結果で説明できるが, $\mathrm{PYP}_{\mathrm{L}}$ と $\mathrm{PYP}_{\mathrm{M}}$ の構造は光れ とは矛盾するという結果になった.

\section{5 . 溶液中での高次構造変化}

さらに, PYPの構造を生理活性との関連で考えると き, 見逃すことができないのは, $\mathrm{PYP}_{\mathrm{M}}$ の結晶構造解析 ではタンパク質の高次構造変化か観測されていないこ とである. 上記の赤外分光によるアミドモードの研究 のほかにも, 多くの研究から $\mathrm{PYP}_{\mathrm{M}}$ で大きく構造変化が 起こっていることが示唆されている.

$\mathrm{PYP}_{\mathrm{M}}$ は, 酸性条件下で安定化される. この性質を利 用して, PYPを酸性 (pH 5.75), 光定常下においた状態 でPYP $\mathrm{P}_{\mathrm{M}}$ を蓄積し, 多次元NMRによる構造解析か試み られた ${ }^{13)}$. $\mathrm{PYP}_{\mathrm{M}}$ の収束構造(得られなかったものの, ${ }^{1} \mathrm{H}{ }^{15} \mathrm{~N}$ HSQC スペクトルから, $\beta 2 \sim \beta 5$ 以外のすべての 部分に大規模な影響がおよんでおり, $\mathrm{PYP}_{\mathrm{M}}$ が非常に緩 んだ構造になっていることが示された. さらに, 暗状態 で内部に埋め込まれていた疎水性残基の一部が溶媒露 出していることも示唆された. また, 我々がX線小角散 乱実験で溶液中のPYP分子の形状を検討したところ, $\mathrm{PYP}_{\mathrm{M}}$ の生成にともなって, 慣性半径が 1 程度増加す ることが示された. このときの散乱パターンの変化は, $\beta$ シート部分の構造変化だけでは説明しきれず, $N$ 末端
部分を含めた大きな構造変化の結果であると考えてい る (発表予定). 一方で, PYP と $\mathrm{PYP}_{\mathrm{M}}$ の結晶構造から $\mathrm{X}$ 線散乱曲線をシミュレートしたところ, 両者の慣性半 径の違いは $0.1 \AA$ ำであり, X線小角散乱実験の検出 限界以下であることがわかった. 以上の結果は, 結晶中 での光反応は, 水溶液中での本来のものとは明らかに 異なり, 生理的条件では $\mathrm{PYP}_{\mathrm{M}}$ でタンパク質全体の構造 変化か泩じることを強く示唆するものである.

\section{6 . 終わりに}

X線結晶構造解析を用いたPYPの光反応メカニズム の研究は, 1995年に暗状態の構造解析か報告された後, わずか 3 年ほどの間に非常に急速なピッチで進められ た. その間には時分割ラウエ法といったタンパク質の 結晶解析では非常に新しい解析法も導入され, 実験手 法に長足の進歩をもたらしたことは無視できない.し かしながら現在, これらで得られた構造は旗色が悪い ようである. 結晶構造解析に誤りがあったとして, 光の 原因には, 結晶中での光反応性が水溶液中と違うこと, 構造解析に先立って十分な状況証拠力湔っていなかっ たこと, 精度が不足している差電子密度マップに基づ いて強引に構造モデルを構築したこと,などが考えら れる. PYP研究の一連の流れのなかでは, インパクトを 求めるあまり, 視覚化された構造か絶対という考え方 が優先されてきた. 产の結果, PYPの光反応過程を正確 に理解する上で, 非常に大きな混乱を引き起こしてい る.X線結晶構造解析は孤高の解析法ではなく, ほかの 技法と組み合わせなければ正確な情報を導き出すこと ができないこともある, という好例であろう. 分光測定 は結晶構造解析が成功するまでの時間稼ぎではないの である.

確かに, 高分解能の構造解析にX線結晶構造解析が 最も有効な手法であることに異議のある方はいないで あろう.ただ, 求めた原子の座標の精度と, 結晶構造解析 でいう分解能とに, 必ずしも相関がないということに 留意するべきである (最近発表されたラウエ法の論文 では, 構造を解かず, 差電子密度の変化か発色団から周 辺に伝播していく樣子を示すにとどまっている(14)). 論 文を読む側も, 結晶構造解析で示された「絵」を鵜吞み にするのではなく, ほかのデータと同じように, 十分に 产の妥当性を検討することか求められるであろう.

\section{文 献}

1) 今元 泰, 德永史生 (1997) 蛋白質核酸 酵素 42, 129135 .

2) Borgstahl, G. E. O., Williams, D. R. and Getzoff, E. D. 
(1995) Biochemistry 34, 6278-6287.

3) Genick, U. K., Borgstahl, G. E., Ng, K., Ren, Z., Pradervand, C., Burke, P. M., Šrajer, V., Teng, T. Y., Schildkamp, W., McRee, D. E., Moffat, K. and Getzoff, E. D. (1997) Science 275, 1471-1475.

4) Genick, U. K., Soltis, S. M., Kuhn, P., Canestrelli, I. L. and Getzoff, E. D. (1998) Nature 392, 206-209.

5) Perman, B., Šrajer, V., Ren, Z., Teng, T., Pradervand, C., Ursby, T., Bourgeois, D., Schotte, F., Wulff, M., Kort, R., Hellingwerf, K. and Moffat, K. (1998) Science 279, 1946-1950.

6) Heberle, J. and Gensch, T. (2001) Nat. Struct. Biol. 8, 195-197.

7) Imamoto, Y., Shirahige, Y., Tokunaga, F., Kinoshita, T., Yoshihara, K. and Kataoka, M. (2001) Biochemistry 40, 8997-9004.

8 ) Brudler, R., Rammelsberg, R., Woo, T. T. and Getzoff, E. D. (2001) Nat. Struct. Biol. 8, 265-270.
9) Xie, A., Kelemen, L., Hendriks, J., White, B. J., Hellingwerf, K. J. and Hoff, W. D. (2001) Biochemistry 40, 15101517.

10) Imamoto, Y., Mihara, K., Hisatomi, O., Kataoka, M., Tokunaga, F., Bojkova, N. and Yoshihara, K. (1997) J. Biol. Chem. 272, 12905-12908.

11) Imamoto, Y., Koshimizu, H., Mihara, K., Hisatomi, O., Mizukami, T., Tsujimoto, K., Kataoka, M. and Tokunaga, F. (2001) Biochemistry 40, 6047-6052.

12) Imamoto, Y., Mihara, K., Tokunaga, F. and Kataoka, M. (2001) Biochemistry 40, 14336-14343.

13) Rubinstenn, G., Vuister, G. W., Mulder, F. A., Düx, P. E., Boelens, R., Hellingwerf, K. J. and Kaptein, R. (1998) Nat. Struct. Biol. 5, 568-570.

14) Ren, Z., Perman, B., Šrajer, V., Teng, T. Y., Pradervand, C., Bourgeois, D., Schotte, F., Ursby, T., Kort, R., Wulff, M. and Moffat, K. (2001) Biochemistry 40, 1378813801.

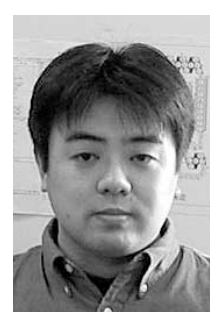

清水伸隆
清水伸隆 (しみず のぶたか)

奈良先端科学技術大学院大学物質創成科学研究科博士後期課程

連絡先 : ₹ 630-0101 奈良県生駒市高山町 8916-5

E-mail: si-nobut@ms.aist-nara.ac.jp

今元 泰(いまもと やすし)

奈良先端科学技術大学院大学物質創成科学研究科 助教授

連絡先 : 同上

E-mail: imamoto@ms.aist-nara.ac.jp

片岡幹雄 (かたおか みきお)

奈良先端科学技術大学院大学物質創成科学研究科教授

連絡先: 同上

E-mail: kataoka@ms.aist-nara.ac.jp

http://mswebs.aist-nara.ac.jp/LABs/kataoka/mainpage.htm 